\title{
TRITIUM MIGRATION IN A/M-AREA GROUND WATER (U)
}

\author{
by
}

R. N. Strom

Westinghouse Savannah River Company

Savannah River Site

Aiken, South Carolina 29808

This is an external document to OSTI

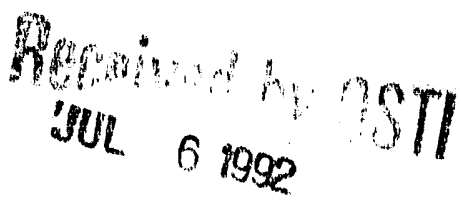

\section{DISCLAIMER}

\begin{abstract}
This report was prepared as an account of work sponsored by an agency of the United States Government. Neither the United States Government nor any agency thereof, nor any of their Government. Neither the Unied States Gor implied, or assumes any legal liability or responsiemployees, makes any warranty, express or implied, or assu information, apparatus, product, or bility for the accuracy, completeness, or usefulness of any ingermately owned rights. Referprocess disclosed, or represents that its use would not in on service by trade name, trademark, ence herein to any specific commercial product, process, or service by trade name, lrademarkmanufacturer, or otherwise does not necessarily constitute or imply its endorsement, The views mendation, of favoring by the United States Government or any agency reflect those of the and opinions of authors expressed herein do not

United States Government or any agency thereof
\end{abstract}

This report was prepared in connection with work done under Contract No. DE-AC09-89SR18035 with the U.S. Department of Energy. By acceptance of this report, the publisher and/or recipient acknowledges the U.S. Government's right to retain a nonexclusive, royalty-free license in and to any copyright covering this report, along with the right to reproduce and to authorize others to reproduce all or part of the copyrighted report.

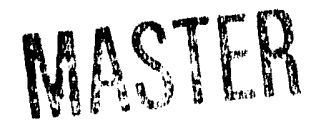


Document No. WSRC-TR-92-8

Donend

D.B. Moore-Shedrow, Section Manager

Authorized Derivative Classifier

TRITILII MIGRATION IN A/M-AREA GROUND WATER (U)

Richard X. Strom

Dawn S. Kaback

Westinghouse Savannah River Company

Savannah River Site

Aiken. SC 29808

Publication Date: January, 1992 


\section{TABLE OF CONTENTS}

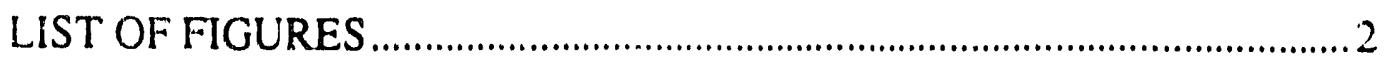

UNITS

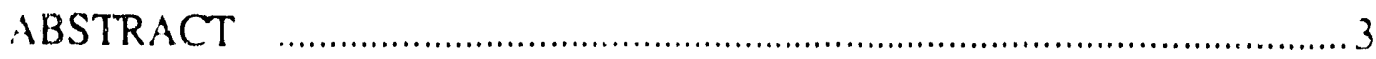

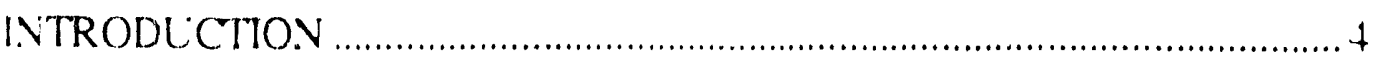

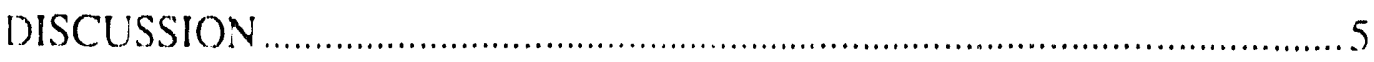

M/M-Area Low-Level Tritium Survey ....................................5

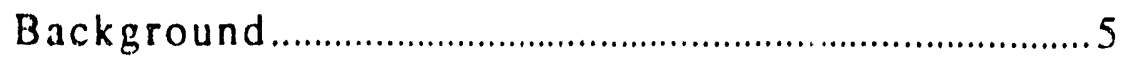

Stratigraphy and Hydrogeology .....................................

Sources of Tritium in A/M-Area Ground Water....11

Tritium Sampling and Analysis................................... 15

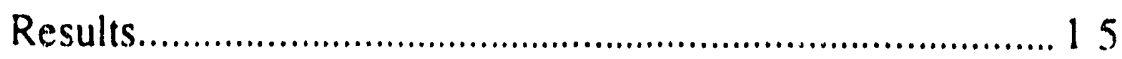

Conclusions and Recommendations............................20

Evaluation of ${ }^{3} 11 /{ }^{3}$ He Datting Technique................................2()

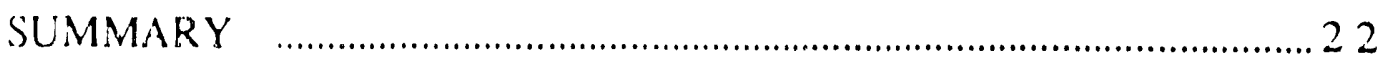

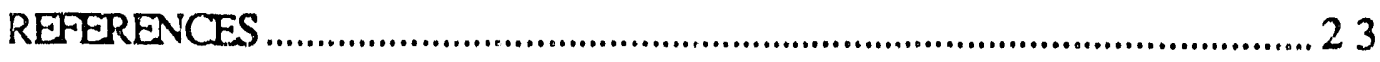

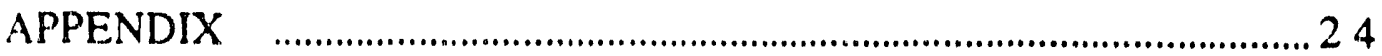




\section{LIST OF FIGURES}

Figure lio.

Page Vin.

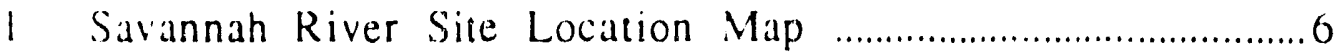

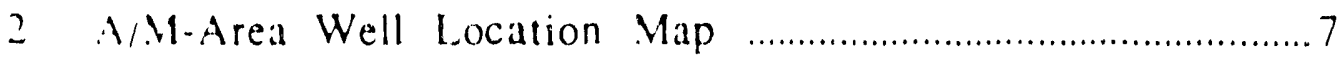

3 Litho- and Hydrostratigraphic Nomenclature......................9

4 Stratigraphic Cross Section through A/M-Area ..................10

5 Potentiometric Cross Section Through A/M-Area............12

6 Tritium Concentrations in Rainfall......................................... 14

7 Decay Corrected Rainfall Data .................................................. 14

8 Classification of Tritium Concentration Levels .................... 16

9) Tritium Data Distribution ........................................................ 17

10 Tritium Concentration vs. Depth...........................................17

11 Tritium Concentrations Cross Section .....................................19

\section{UNITS}

Tritium Lnits (TU)

1 TU $=1$ 'H per 1018 Hydrogen Alom

$1 \mathrm{TU}=3.2 \mathrm{pCi} / \mathrm{L}$

TU $/ 312.5=1 \mathrm{pCi} / \mathrm{ml}$

Drinking Water Standard $=20 \mathrm{pCi} / \mathrm{ml}$

$$
=6,250 \mathrm{TU}
$$




\section{ABSTRACT}

Volatile organic compounds (VOC's) have entered aquifers in Cretaceous-aged sediments in the A/M-Area as a result of site operations. Tritium in A/M-Area ground water was investigated as a tracer to determine the movement of ground water in the subsurface and the transport mechanism of VOC's. The investigation wats focused primarily on determining the continuity and integrity of the clay layers in the Ellenton Formation and their effectiveness as aquitards below the aquifers in Tertiary sediments.

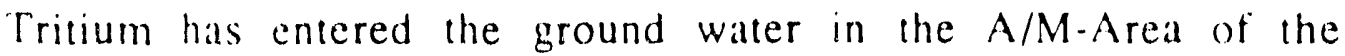
Savannah River Site (SRS) from several sources. Precipitation has included natural cosmogenic tritium, "bomb tritium" from aboveground testing of nuclear weapons, and tritium released into the atmosphere from SRS facilities. Tritiated water has also been released directly into ground water from point sources such as seepage basins and outfalls by various facilities in the $A / M$ Area.

Over much of the study area the Ellenton Formation serves as a barrier to downward migration of ground water. Beneath the A-Area however, ground water derived from precipitation during the past forty years has penetrated through the Ellenton Formation into the Steel Creek Member of the Peedee Formation; that is, from the water-table aquifer into aquifer unit I/IIB, a drinking water source in the region. The Ellenton is much sandier in this area and apparently provides conduits for groundwater movement under the influence of the downward hydraulic gradient.

Also beneath the A-Area, a pod or plume of ground water containing tritium in concentration above ambient rainfall tritium was detected in the shallow aquifer. Some samples from this plume or pod contained tritium in excess of drinking water standards. The most probable source of this water is the seepage basins or drains and cutfalls in the Savannah River Laboratory area. 


\section{INTRODUCTION}

Artificial tracers are commonly used to investigate the movement and dispersion of ground water. In most instances however, the usefulness of the tracers is limited by the short durations of the experiments, by the large dilution effects of groundwater mixing, and by physical or chemical reactions between the framework materials of the aquifer and the tracers. In recent years, tritium has been found to he an extremely useful tracer because it occurs in ground water as part of the water molecule and because rainfall was "spiked" with tritium over the northern hemisphere during the early" 1960's by thermonuclear weapons testing programs. At the Savannah River Site. local sources have also contributed to the levels of tritium detected in rainfall.

The current investigation was undertaken to determine whether tritium could be used as a tracer of groundwater movement in the A/M-Area. In particular, discontinuities in the aquitard separating the shallow aquifers in Tertiary sediments from the deeper aquifers has been inferred based on geologic information and on contamination of 2 production wells in the $\mathrm{A} / \mathrm{M}$-Area by volatile organic compounds (VOCS). This investigation focused on determining whether recent precipitation has infiltrated through the aquitards into the aquifers in the Cretaceous-aged sediments below the confining layers.

In most areas of the world, the infiltration rates of recent, tritiumenriched rainfall can be measured based on the migration rates of the tritium spike from the weapons testing programs. Because tritium has a relatively short half-life, about 12.3 years, naturally occurring tritium is in very low concentrations $(<.005 \mathrm{pCi} / \mathrm{ml})$ in ground waters older than about the mid 1950's making it possible to distinguish between recent and these pre-1950's water.

The decay of tritium produces ${ }^{3} \mathrm{He}$ as a daughter product and, as another portion of the study, a review of recent research on ${ }^{3} \mathrm{He} /{ }^{3} \mathrm{H}$ dating techniques was undertaken to determine if this dating method could be used at the Savannah River Site (SRS) to calculate vertical and horizontal groundwater flow rates. While ${ }^{3} \mathrm{He}$ measurements were not undertaken for this study, this information was assessed to cietermine whether future studies would benefit from this technique. 


\section{DISCUSSION}

\section{A/M-Area Low-Level Tritium Survey}

\section{Background}

The Savannah River Site occupies a portion of the Aiken Plateau (Siple, 1967) within the Atlantic Coastal Plain Province. The A/MArea is located in the northwest portion of the site (Figure 1). Most of the facilities in the $\mathrm{A} / \mathrm{M}$ Area (Figure 2) are located on the the level plateau portions of the site. The area on the eastern side of $\mathrm{A} / \mathrm{M}$-Area has been dissected hy several small gullies that lead into Tims Branch, an intermittent stream tributary of Upper Three Runs. On the western side of the A/M-Area, drainage is into a closed depression called "Lost Lake" and toward an unnamed drainage basin on the fringe of the Savannah River flood plain. The relief on the area shown in Figure 2 is approximately 180 feet.

\section{Stratigraphy and Hydrogeology of A/M-Area.}

The major water-bearing units beneath the A/M-Area are Cretaceous and Tertiary clastic sediments, primarily silicate sands and clays, deposited in terrestrial to shallow marine environments. The clastic requence is from 700 to 800 feet thick and was deposited on a basement composed of Paleozoic and Precambrian metamorphic and igneous rocks.

As is characteristic of nearshore deposits, the depositional environments of the principal sedimentary units change dramatically over short lateral distances. Similarly, there are significant changes in the depositional environments with time, resulting in rapid vertical changes in lithology. Discontinuities in the depositional record are indubitably common but not always clearly identifiable on the basis of available cores. As a consequence of these conditions, many units in the A/M-Area are not easily correlated across an area or to lithologies at the type localities of established stratigraphic units. As a consequence, the stratigraphic nomenclature applied to $A / M$ Area has been successively modified and reinterpreted based on the predilections of various investigators. 


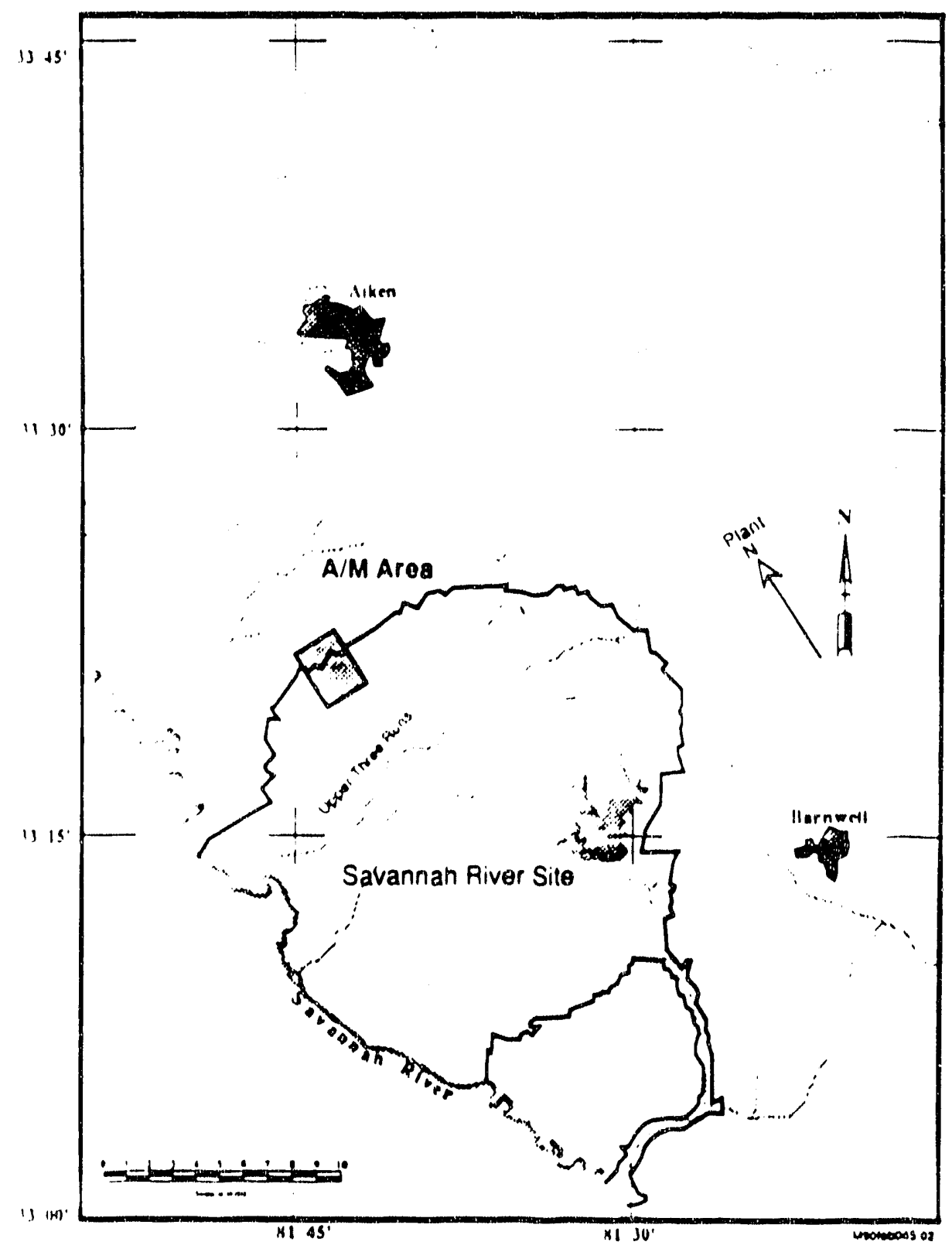

Figure y Savannan River Site location map and study area. 


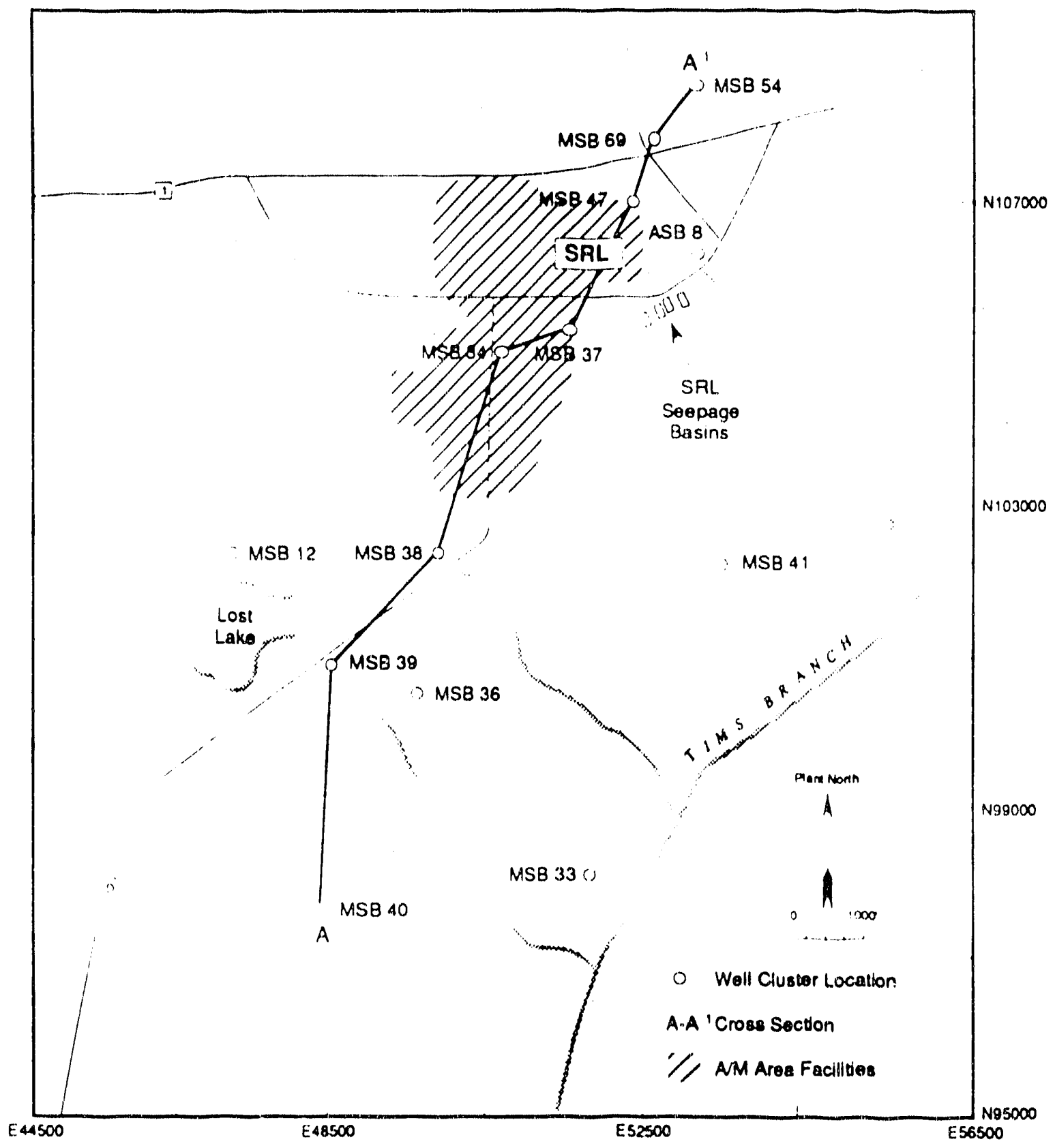

Figure 2. AM.Area well location map. 
The most recent interpretation of the $\mathrm{A} / \mathrm{M}$-Area lithostratigraphy, and the one used in this study, is that of Fallaw (1990). Figure 3 compares the stratigraphic interpretations of Fallaw with those of previous investigators. The interpretations and nomenclature of Siple (1967) have been widely used on the Savannah River Site and have provided a point of departure for subsequent stratigraphic interpretations. Bledsoe (1988) modified the terminology used by Siple hased on a detailed lithologic examination of cores collected for the SRS regional hydrogeologic baseline investigation and on a review of current literature on Coastal Plain stratigraphy. Fallaw (1990) has recommended some modifications to the nomenclature applied to the $\mathrm{A} / \mathrm{M}$ Area stratigraphy based on lithological and paleontological examination of cores from the $\mathrm{A} / \mathrm{M}$-Area.

Figure 4 shows a cross section through the $A / M$-Area. The lops and hottoms of the formations were picked from Fallaw $(19(9))$. Fallaw's study, as well as those of early investigators, shows that there is considerable lithologic variation within each stratigraphic unit across the study area. For instance, both the "green clay" that marks the base of the Santee Formation, and the "tan clay" at the top of the formation, are discontinuous in the $A / M$ area and cannot be traced in cross section. In the southern portion of the Savannah River Site. these heds provide excellent stratigraphic marker horizons and hydrogeologic boundaries.

The terminology used for the hydrostratigraphy in the area has likewise evolved. Aadland and Bledsoe (1990) have suggested dropping the traditional names of the major water-bearing units that correspond to formational names, such as the "Congaree Aquifer," etc., in favor of a nomenclature that is independent of stratigraphic interpretations. A comparison between the lithostratigraphic and the proposed hydrostratigraphic nomenclature is illustrated in Figure 3. In the $\mathrm{A} / \mathrm{M}$-Area, the principal transmissive units are separated by less transmissive zones. or aquitards, corresponding 10 clay-rich heds. These aquitards occur in the A/M-Area at the base of the Santee Formation ("green clay"), throughout the thickness of the Ellenton Formation, and within the Steel Creek Formation. The continuity of the aquitards and their ability to retard the migration of water and contaminants is the subject of several current investigations includin? this study. 


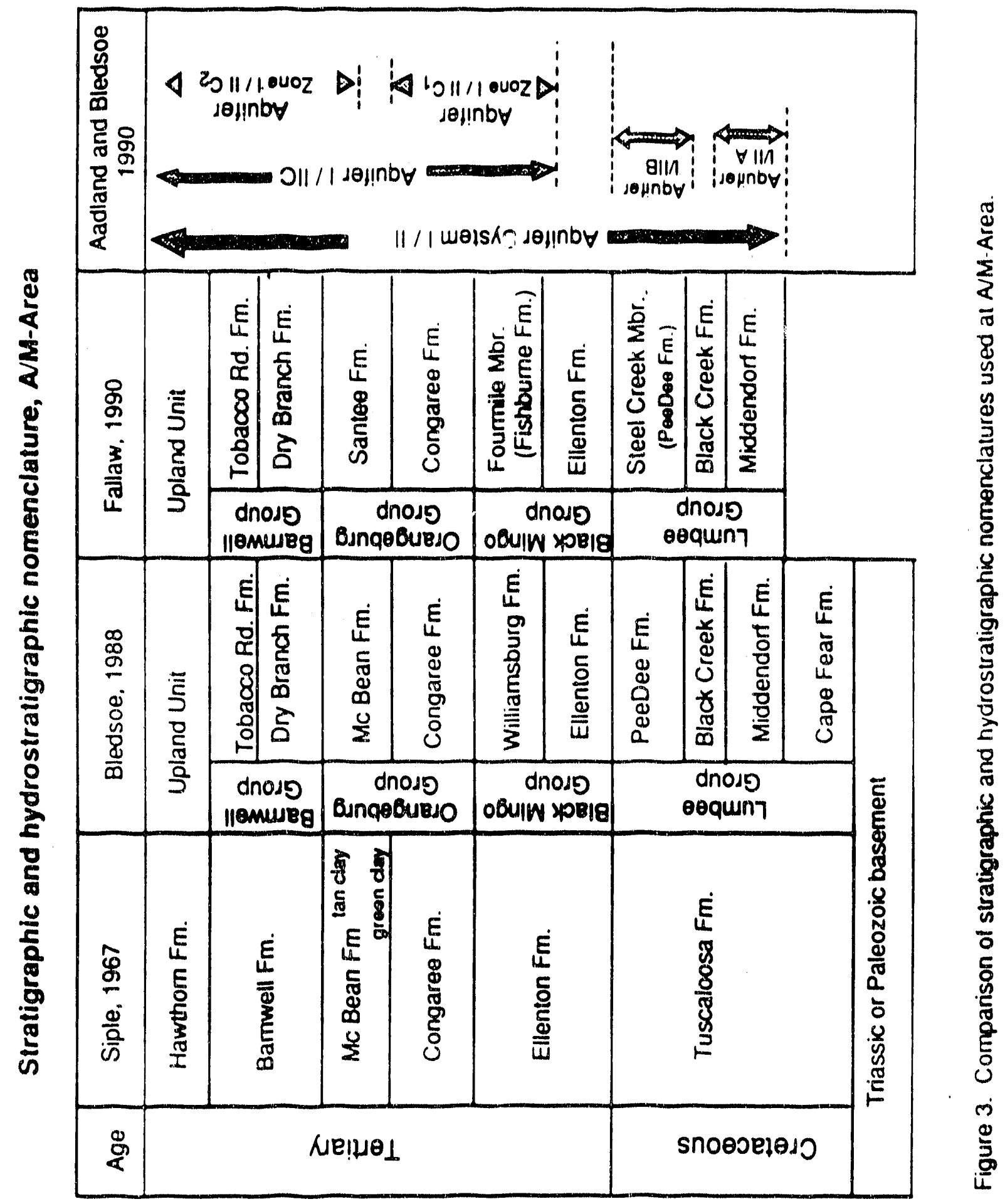




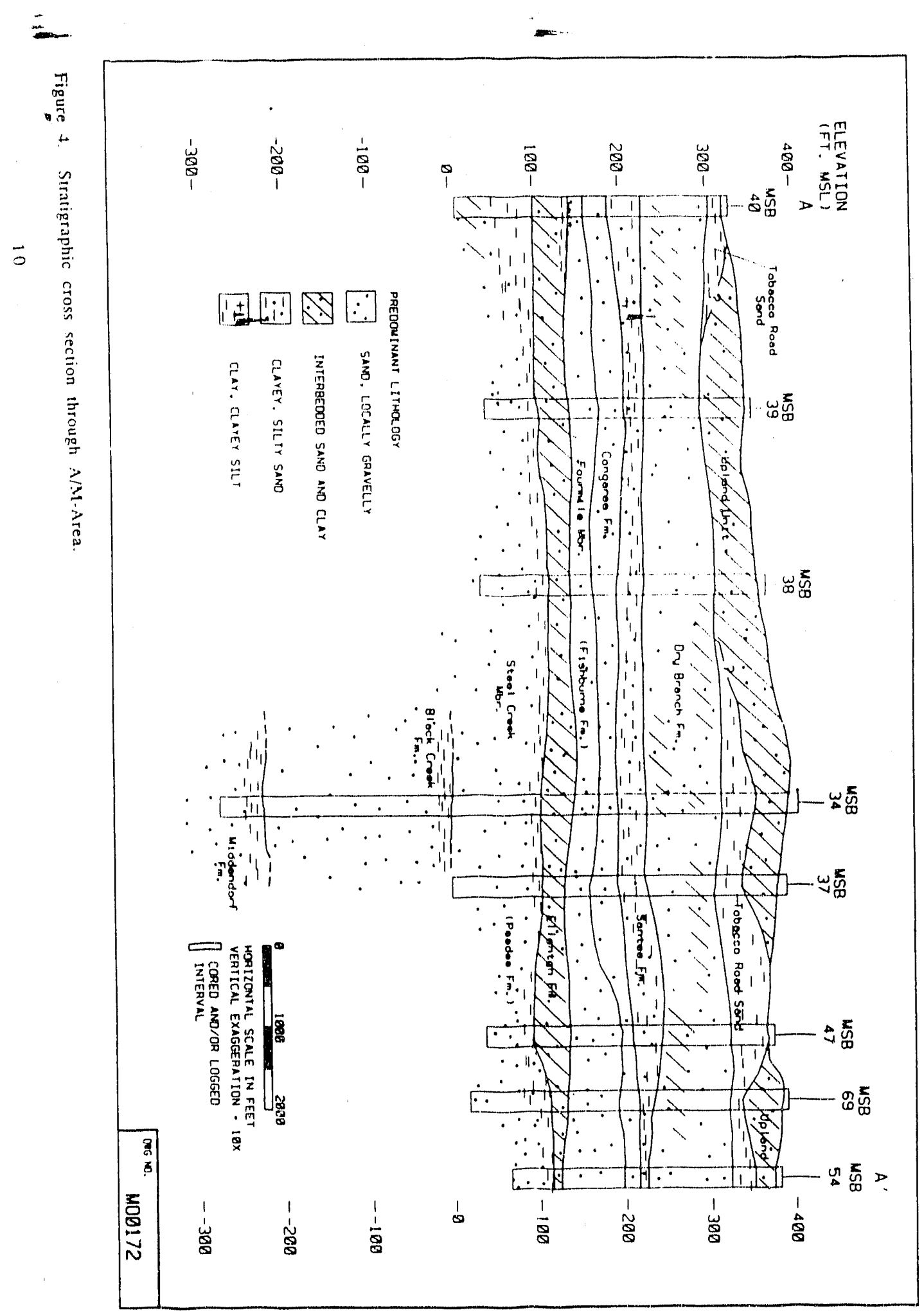


The hydrologic effects of the various aquitard units are evident when water level data are plotted on the cross section through the area (Figure 5), particularly on the southern end of the section. The convergence of the potentiometric contours near the tops of the Santee and Steel Creek Formations shows areas of steep hydraulic gradients corresponding to low permeability zones. In the northern portion of the study area, the spreading of the potentiomeiric contours suggests that separation of the lower aquifer from the shallow aquifer units is less effective.

\section{Sources of Tritium in $A / M$ Area Ground Water}

Tritium ras entered the ground water in the $\mathrm{A} / \mathrm{M}$-Area from several sources. These sources include naturally produced cosmogenic tritium deposited by rainfall, "bumb tritium" from above-ground testing of nuclear weapons, tritium released into the atmosphere from SRS facilities, and tritiated water released from point sources by various facilities in the A/M-Area.

Tritium is produced naturally in the upper atmosphere and leaks through to the troposphere during late winter months. The concentrations of natural cosmogenic tritium in precipitation vary seasonally and, depending on geographic location, may range from t tritium units (TU) to $25 \mathrm{TU}(0.013$ to $0.08 \mathrm{pCi} / \mathrm{mi})$. The concentrations are generally higher by a factor of about five in localities above $30^{\circ}$ latitude (Gat, 1980).

Massive amounts of tritium were injected into the atmosphere by thermonuclear weapons testing programs during the late 1950's and especially during the early 1960's. The International Atomic Energy Agency has maintained stations to monitor tritium in rainfall. The locality with the longest continuous monitoring record is Ottawa, Canada. Because of its completeness, the Ottawa record is frequently referred to for comparison purposes. This record, illustrated in Figure 6. shows a pronounced spike in 1963. shortly preceding the ban on above-ground testing. The weighted mean tritium concentration in rainfall was almost $3,000 \mathrm{TU}(9.6 \mathrm{pCi} / \mathrm{ml})$. This 1963 spike in the precipitation tritium record has been widely observed throughout the northern hemisphere. It has been useful as a tracer to study the infiltration and dispersion rates of rainwater in shallow aquifers (Hendry, 1983; Egboka et al., 1983; and Allison and Hughes, 1974). 


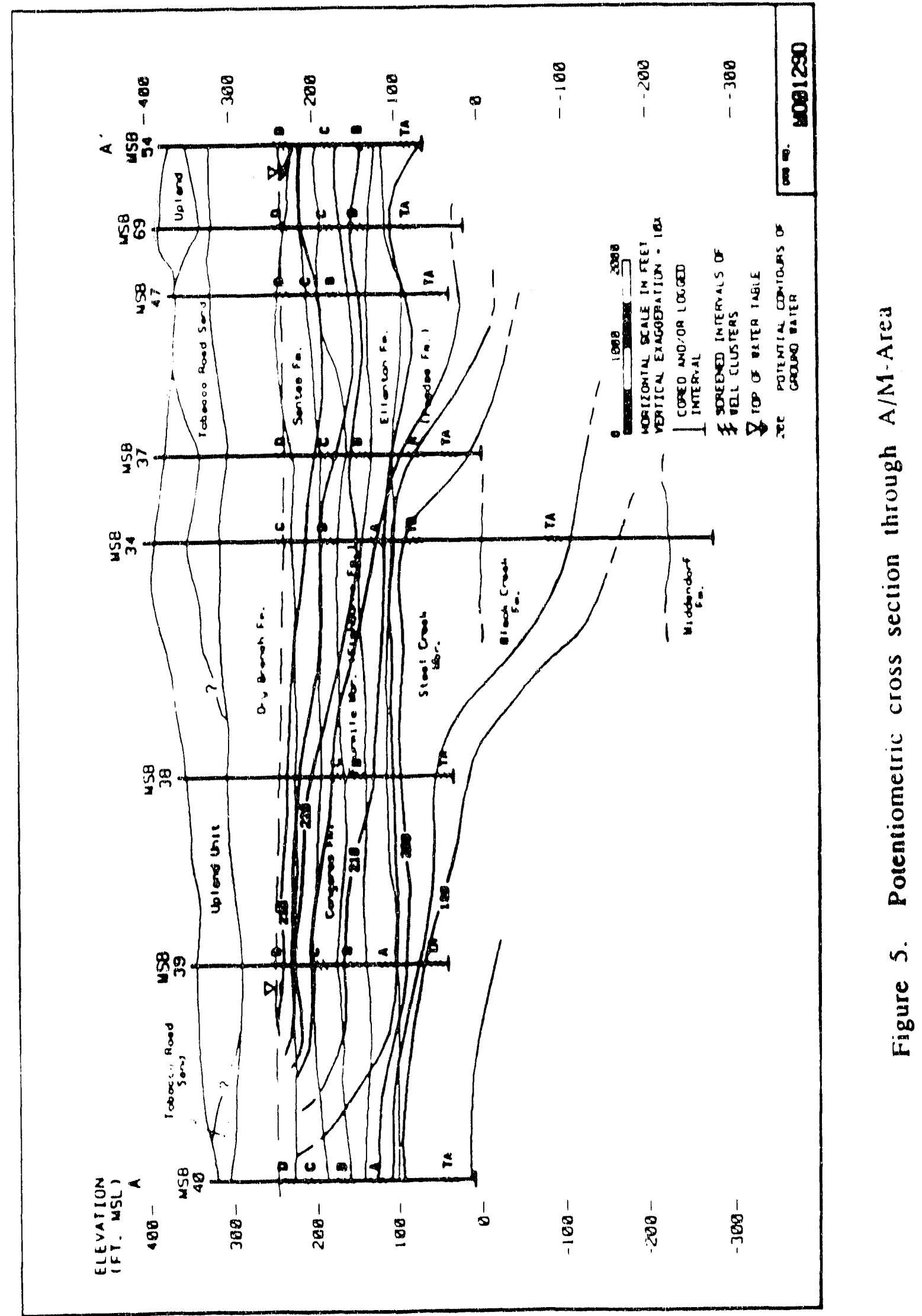


At SRS. the signatures of both natural tritium and of "bomb" tritium in rainfall are masked by the amount of locally produced tritium reaching the water table from precipitation and point sources. The 1963 tritium tagged waters are not likely to be discernable from the locally produced tritium. Murphy et al. (1990) have reviewed and summarized many of the data on tritium in the SRS environment. The vast majority of the tritium in the ground water at SRS comes from release of tritium to the atmosphere by on-site facilities. Over the period 1954101988 approximately $24 \times 10^{6}$ curies have been released 10 the atmosphere, primarily from the separations areas and secondarily from the reactors. The average annual release of about $11.7 \times 10$ is about $1 / 10$ th of the total natural production of tritium in the upper atmosphere, estimated to be about 4 to $8 \times 10^{6} \mathrm{Ci} / \mathrm{yr}$.

About half of the tritium released at SRS is in the form of elemental tritium (HT) and about half as tritiated water (HTO), that is as a normal water molecule with tritium replacing one of the hydrogen ions in the molecule. Tritiated hydrocarbons such as methane are also detected but are not quantitatively significant compared to the other two forms. On-site deposition of HTO is accomplished primarily through wash-out by precipitation. Semi-quantitative estimates of the precipitation tritium can be derived for many of the areas in and around the site. Direct measurement data have also been collected in precipitation tritium from a rain gage just north of the $A / M$ Area since 1973 and from the A-Area since 1988 (Murphy et al., 1990)).

At the latitude of SRS, the 1963 tritium spike would not be as pronounced as at Ottawa due to circulation patterns in the upper atmosphere. The peak concentrations from thermonuclear weapons testing would be about $1 / 2$ to $1 / 3$ rd that of Ottawa (Egbota et al., 1983) and would be more nearly comparable to the concentration in rainfall at A/M-Area during the late 1980's. Furthermore, because the half-life of tritium is relatively short (12.3 yrs.), the spike will have decayed significantly by the time sampling of ground water took place for this study. The mean annual concentrations from these stations are shown on Figure 6 for comparison to the Ottawa record.

When the precipitation data are corrected for decay (Figure 7), it becomes evident that it would be difficult to pick out the "bomb tritium" peak from the other sources of precipitation tritium at the $\mathrm{A} / \mathrm{M}$-Area. In general, the younger waters should have higher 
tritium concentration 'n rainfall

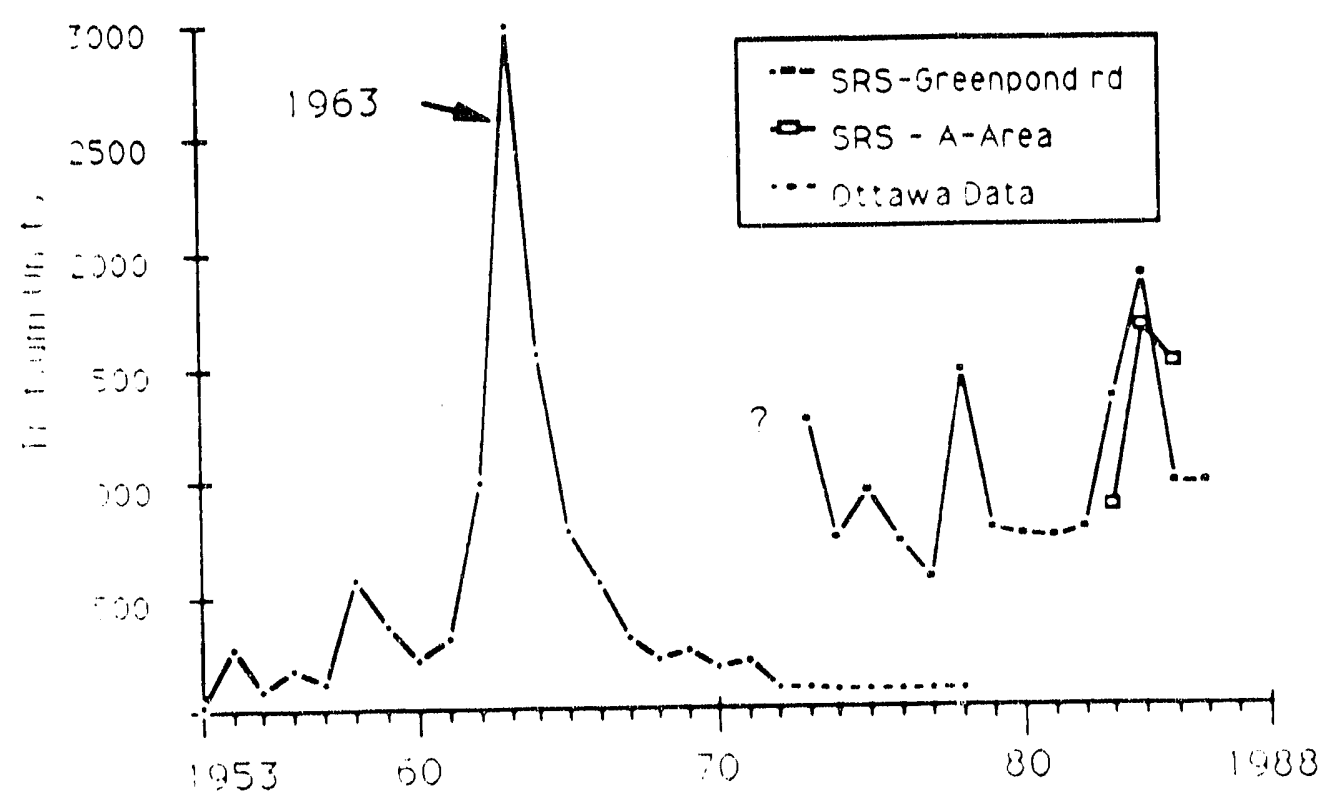

F zure 6 . Concentrations of tritium in rainfall at the $A / M$-Area and at $\because$ awa. Canada

Decay corrected rainfall data (1988)

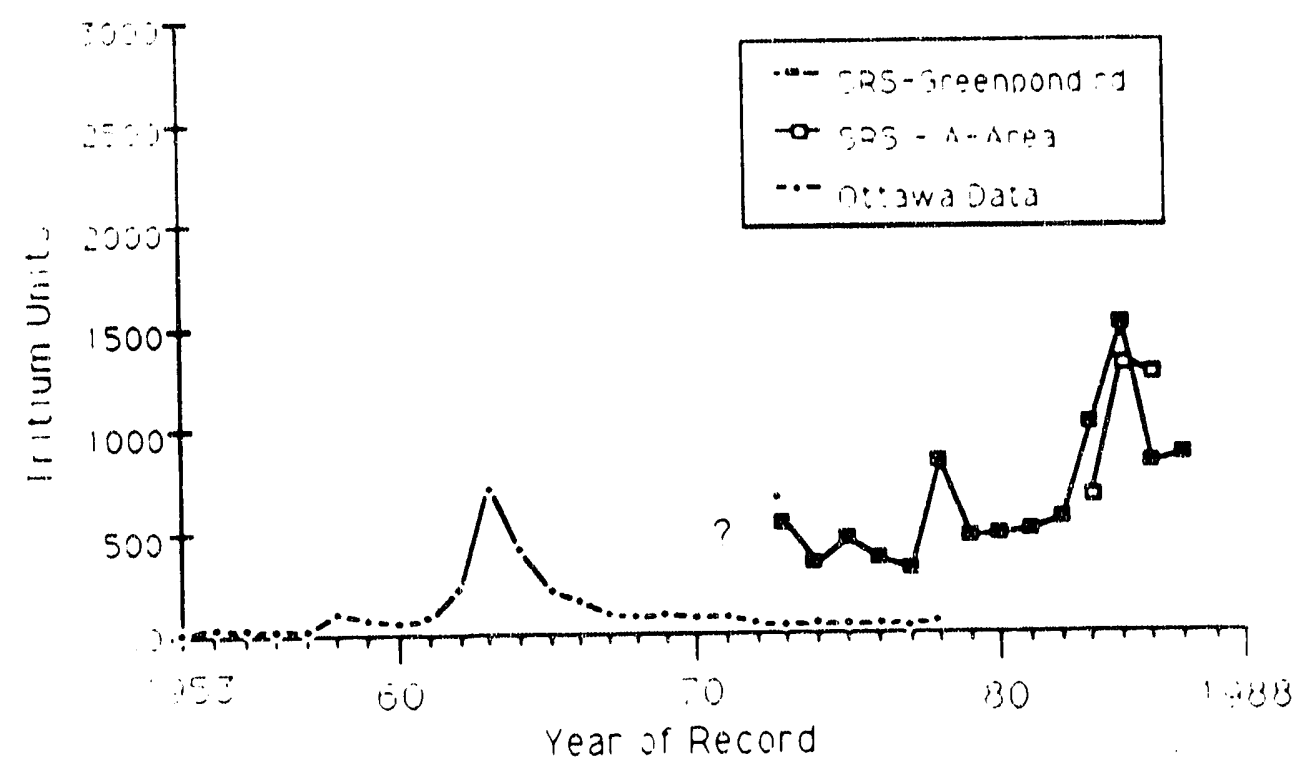

$=$ jure - Tr.tum concentration 'n rainfall corrected for decay to 1988 
oncentrations and there should be an approximately inverse ip between tritium concentration and age since the period id-1950's. The maximum concentration of precipitation groundwater should be in the range of 1.000 to $1.500 \mathrm{TU}$ isis of 1988 decay corrected data.

these data, a rudimentary time scale classification of ater ages can be devised (see Figure 8). Ground water or scharges with tritium concentrations below about 10 TU derived from groundwater reservoirs containing waters that prior to the beginning of the thermonuclear testing and up of reactors at SRS. Modern waters, i.e. precipitation that the ground water since the late 1950's or early 1960's will es ranging from 100 TU to about 1,500 TU. Any water with an about 1500 TU must have a local point source origin.

$i$ different age waters as well as imprecision in the analytical ; produce uncertain age designations.

\section{Sampling and Analysis}

e spring and early summer of 1989,61 wells in the A/M? sampled for tritium. The wells sampled are from 13 clusters that are aligned approximately NE to SW across the 1. Five of the wells were sampled in duplicate to determine lucibility of the sampling and analytical procedures. The of the 13 well clusters are shown on Figure 2. The samples ected using standard well purging procedures and tritium flasks. The Environmental Transport Section (ETS) ics Laboratory analyzed each of the samples in duplicate ETS low-level tritium counting facilities. The results of lyses as well as other pertinent well and sample data are ppendix I.

shows a histogram of the tritium analytical results. The vast if the analytical data fall between 0 and 1,500 TU, i.e. : range anticipated from the infiltration of rainwater into face. Two of the samples, ASB 8 C and MSB 47C are far in what would be expected based on the previous discussion ssumed to have a point source origin. The most probable this water is the seepage basin or drains and outfalls in the River Laboratory area. 
AGE CLASSIFICATION CF GROUND WATER USING TRITIUM DATA

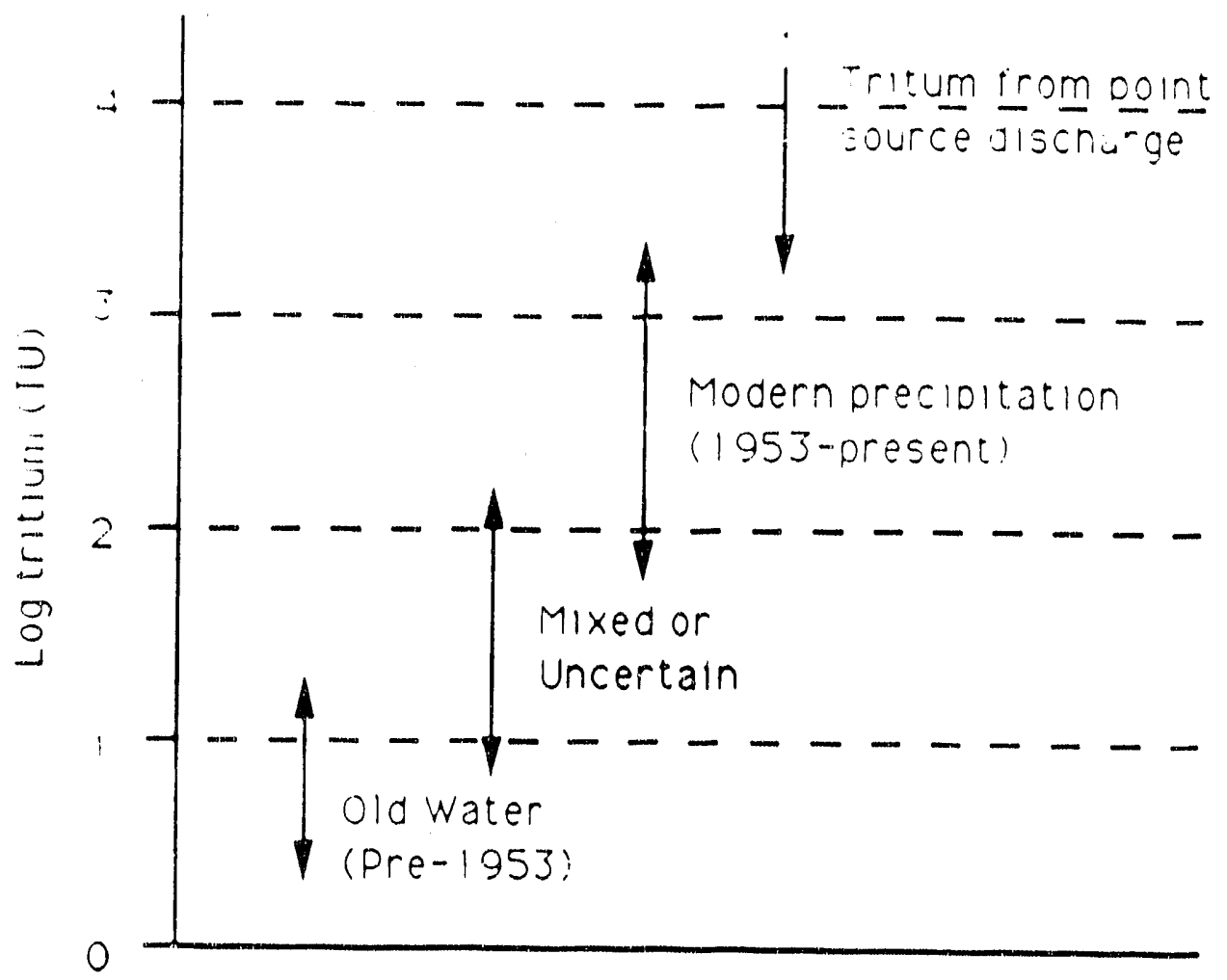

Figure 8. Age classification of tritium concentration levels. The age of ground water can be broadly categorized on the basis of tritium concentrations. Water containing tritium in concentrations greater than about 100 TU has entered the ground water since the beginning of operations at the Savannan River site 


\section{A/M Area tritium data distribution}

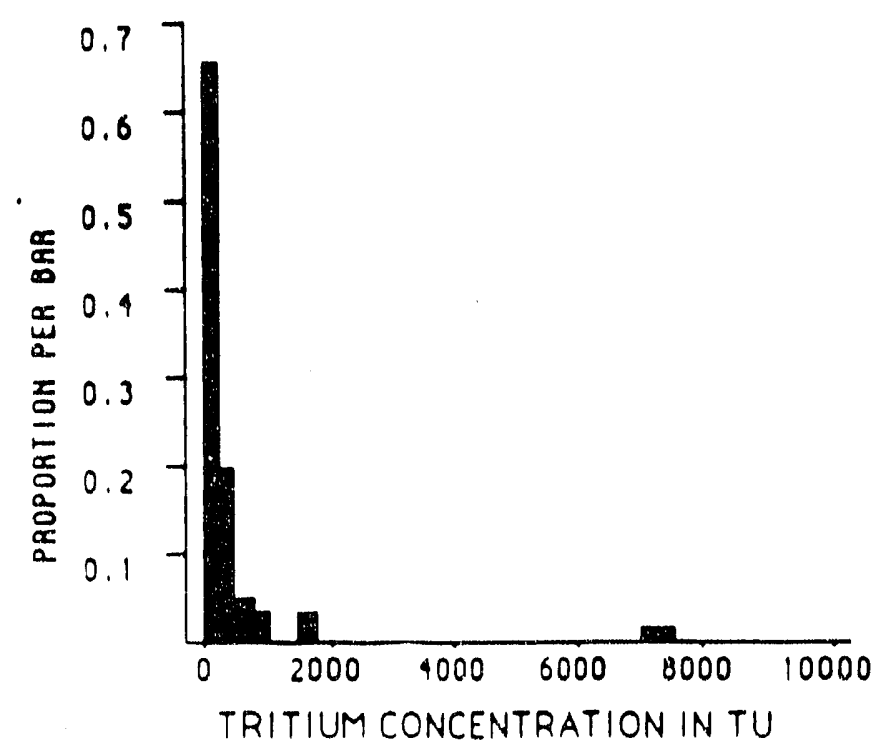

Figure 9 Histogram of tritlum value distribution. The outlying values are assoclated with a point source of tritlum.

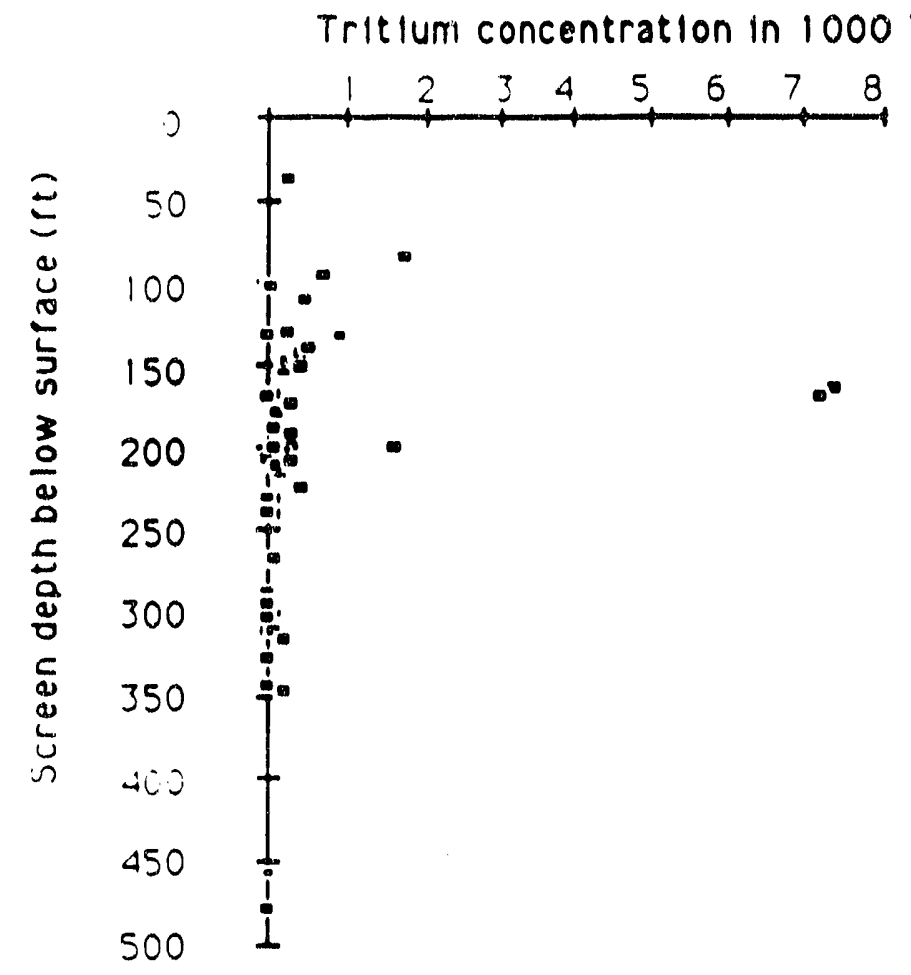

Figure 10. Tritum concentration versus depth. 
A large number of the samples have tritium concentration values below $100 \mathrm{TU}$. These low values indicate water ages greater than about 30 years. When plotted as a function of depth, Figure 10, the highest tritium activities are generally at shallower depths however the obverse is not necessarily true. Older waters with tritium values less than $100 \mathrm{TU}$ are found in shallow as well as in the deep wells.

While most of the samples from below the clay-rich beds of the Ellenton Formation have low tritium concentrations, tritium-rich waters have penetrated through these confining beds in the vicinity of the Savannah River Laboratory. These modern waters are found in the Cretaceous-aged sediments of Aquifer I/IIB in wells MSB $37 \mathrm{TA}$ and MSB 47TA and possibly in well MSB 37A (Figure 11). The iritium concentrations are consistent with values expected in rainwater deposited during the years since 1953. Measurable TCE concentrations are detected in these same wells, apparently having migrated into the Steel Creek Member concurrently with the downward migration of modern ground water and not as a separate dense non-aqueous phase liquid (DNAPL).

The hydraulic gradient in A/M-Area has been discussed above. Over much of the the A/M-Area there is a consistent downward hydraulic gradient from the water table into aquifer I/IIB. (see Figure 5 above). In the vicinity of the Savannah River Laboratory (SRL) in the northern portion of the study area, sufficient permeability apparently exists to allow penetration of the modern waters through the Ellenton Formation confining beds. The origin of this high permeability zone in the aquitard is unknown at present, however several hypotheses have been suggested. In the vicinity of well clusters MSB 37 and MSB 47, moderately to well-sorted sands are uncharacteristically common and the confining beds of the Ellenton Formation thin on the north and eastern edges of the study area (Fallaw, 1990). In addition to the lithologic changes in the area, structural factors may contribute to the existence of a high permeability zone in the confining units.

Seismic reflection surveys have shown the existence of faulting in the crystalline basement rock below the A/M-Area. Fallaw (1990) has suggested that the fault may extend through the Tertiary section displacing or interrupting the lateral continuity of the aquitards in the section. The tritium data in the present study, however, do not indicate downward migration in the vicinity of well cluster MSB 34 that sits astride the possibly faulted section. 


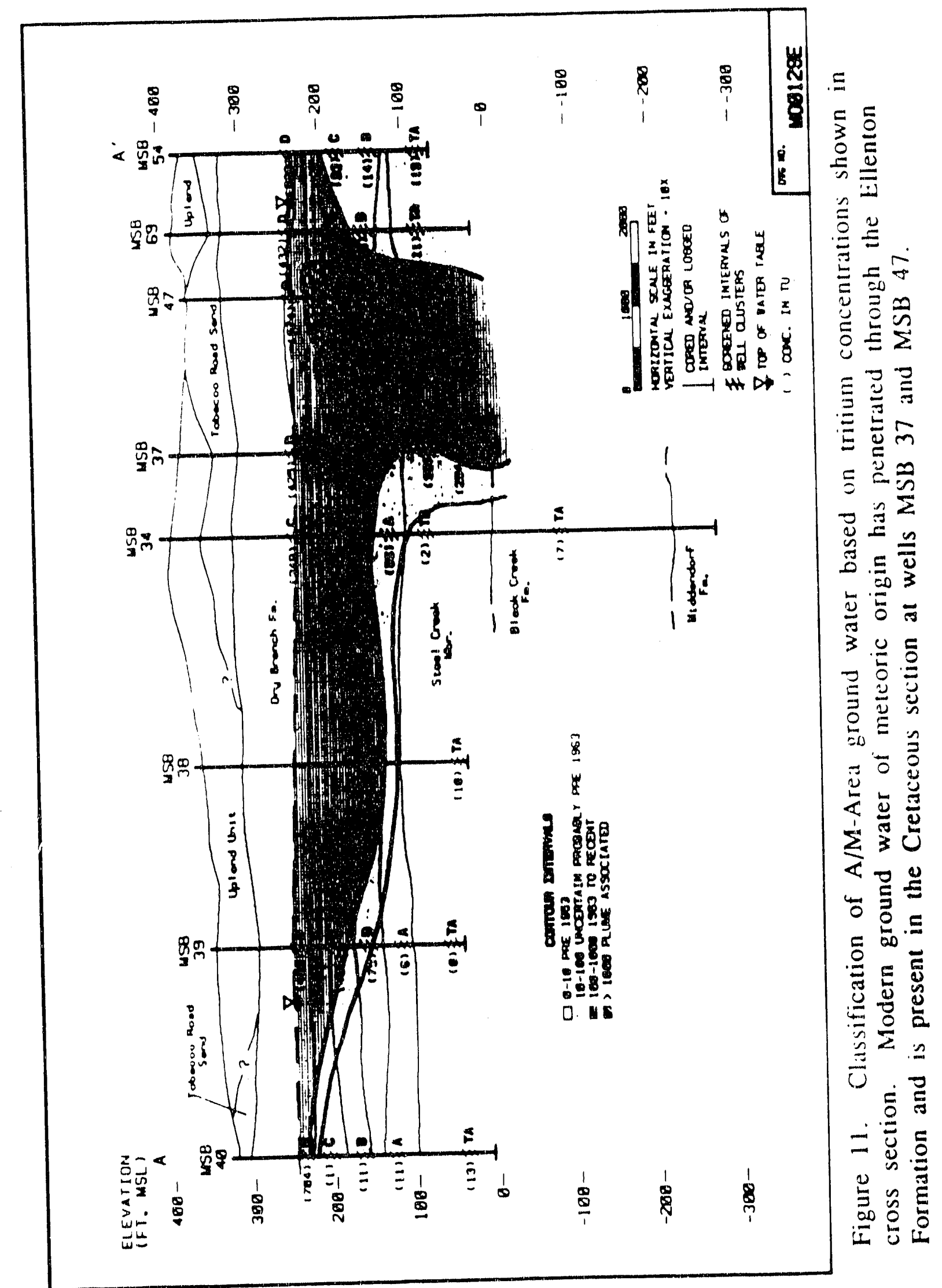


The sedimentalogical features noted by Fallaw, thinning of the confining beds and localized well-sorted sands, combined with the downward hydraulic gradient seem to adequately explain the downward movement of water into the Cretaceous Steel Creek Member of the Peedee Formation.

\section{Conclusions and Recommendations}

Tritium surveys using the low-level analytical facilities at SRL could he especially effective as an analytical tool at the Savannah River Site. L'nlike many areas of the North American Cuntinent where the majority of the tritium in ground water was received during the peak years of above-ground weapons testing, the Savannah River Site has had a nearly continuous supply in the rainwater since the beginning of reactor operations. Because the tritium moves as part of the water mass and is not noticeably involved in chemical or physiochemical reactions, it provides a valuable tracer for the movement of modern ground water. In the present study for instance, the results verify the earlier proposals that a pathway exists for the downward migration of shallow ground water into the Cretaceous sediments below the Ellenton Formation.

\section{Discussion of ${ }^{3} \mathrm{H} /{ }^{3} \mathrm{He}$ Dating Techniques}

A considerable amount of additional information could be obtained through incorporation of $3 \mathrm{H} /{ }^{3} \mathrm{He}$ age dating techniques into future tritium investigations. Tritium decay in ground water will produce helium-3 as a daughter product through beta decay,

1) ${ }^{3} \mathrm{H} \rightarrow{ }^{3} \mathrm{He}+\beta$.

So long as the system is closed to prevent escape of the ${ }^{3} \mathrm{He}$ to the atmosphere, the age of the water mass can be calculated

$$
\text { 2) } \begin{aligned}
t \cdot \frac{\mathrm{He}^{*}}{{ }^{3} \mathrm{H}}= & \lambda-1 \ln \left[\frac{{ }^{3} \mathrm{He}^{*}}{{ }^{3} \mathrm{H}}+1\right] \\
& \text { where }{ }^{3} \mathrm{He}^{*}=\text { tritogenic }{ }^{3} \mathrm{He} .
\end{aligned}
$$

Within the vadose zone and in the upper few centimeters of the phreatic zone, the system must be considered to be an open system. However, both field studies and theoretical calculations show that below the water table, the system is closed with respect to tritiogenic 
${ }^{3}$ He. Solomon and Sudicky (1991) have mathematically modeled the effects of dispersion and calculated differences between true groundwater travel times and ${ }^{3} \mathrm{H} /{ }^{3} \mathrm{He}$ ages. Under conditions such as those encountered in the shallow aquifer zones at SRS, the differences will be relatively small, probably less than $10 \%$.

Two types of information would be available from ${ }^{3} \mathrm{H} /{ }^{3} \mathrm{He}$ age dating: (1) shallow groundwater flow models can be accurately calibrated against known travel times through $3 \mathrm{H} / 3 \mathrm{He}$ dating. This would be especially useful in developing models in complex flow systems where solute transport of contaminants is of concern. (2) Since in a closed system.

$$
\begin{array}{ll}
{ }^{3} \mathrm{H}_{\mathrm{O}}={ }^{3} \mathrm{H}_{\mathrm{m}}+3 \mathrm{He}^{*} \text { where: } & 3 \mathrm{H}_{\mathrm{O}}=\text { original }{ }^{3} \mathrm{H} \text { in precipitation } \\
& { }^{3} \mathrm{H}_{\mathrm{m}}=\text { measured tritium } \\
& { }^{3} \mathrm{He}^{*}=\text { tritiogenic } 3 \mathrm{He} .
\end{array}
$$

a historical record of the atmospheric transport and deposition of tritium to distant or to unmonitored areas can be reconstructed based on groundwater measurements. This might be especially useful in addressing questions relating to the long term exposure of residents in the vicinity of SRS.

Methods for measuring low concentrations of tritium in atmospheric and aqueous samples have been developed and are routinely used at the Savannah River Site. The Savannah River Laboratory also has the instrumentation to perform a limited number of ${ }^{3} \mathrm{He}$ measurements and ${ }^{3} \mathrm{He} /{ }^{4} \mathrm{He}$ ratio's. The mathematical treatment for determining ${ }^{3} \mathrm{H} /{ }^{3} \mathrm{He}$ ages has been developed and mathematical algorithms using these data to determine flow rates, dispersion coefficients, and recharge rates are maturing. 


\section{SUMMARY}

Atmospheric transport and deposition of tritium in rainwater have created a unique signature to modern groundwater, which allows its use as a tracer. In the A/M-Area, modern waters have mostly been confined to aquifers above the Ellenton Formation. In one section near the northern end of the study area, modern, post 1950's waters have penetrated into the Cretaceous-aged Steel Creek Member of the Peedee Formation. Sedimentary features appear to be adequate 10 explain the increase in permeability of the overlying aquitards.

The usefulness of tritium as a tracer would be greatly augmented if future studies are combined with ${ }^{3} \mathrm{H} /{ }^{3} \mathrm{He}$ dating techniques. These age-dating techniques are rapidly maturing and should be used routinely for on-site investigation of shallow groundwater movement and contaminant transport. 


\section{REFERENCES}

Aadland, R.K. and H. W. Bledsoe, 1990, Classification of Hydrostratigraphic Units at Savannah River Site, South Carolina (U), WSRC-RP-90-987, 15 pp.

Allison, G.B., and M.W. Hughes, 1972, Comparison of recharge to groundwater under pasture and forest using environmental tritium, Jour. of Hydrology, v. 17, nos.1/2, p. 81-95.

Bledsoe, H.W., 1988, SRP Baseline Hydrogeologic Investigation Phase III, DPST-88-627, E.I. duPont de Nemours \& Co., Savannah River Laboratory, Aiken, SC.

Egboka, D.C.E.. J.A. Cherry, R.N. Farvolden, and E.O. Frind, 1983, Migration of contaminants in groundwater at a landfill, a case study, 3, tritium as an indicator of dispersion and recharge, Jour. of Hydrology, v. 63, p. 51-80.

Fallaw, W.C., 1990, Subsurface Stratigraphy and Structure of A/M Area (U), WSRC-RP-91-0830, ca. 60 pp.

Gat, J.R., 1980. The isotopes of hydrogen and oxygen in precipitation, in Fritz. P., and J.Ch. I ttes (eds.), Handbook of Environmental Isotope Geochemistry, v. 1, Amsterdam, Elsevier, p. 21-47.

Hendry, M.J., 1983, Groundwater recharge through a heavy-textured soil, Jour. of Hydrology, v. 63, p. 201-209.

Murphy, C.E., Jr., L.R. Bauer, D.W. Hayes, W.L. Marter, C.C. Zeigler, D.E. Stephenson, D.D. Hoel, and D.M. Hamby, 1990, Tritium in the Savannah River Site Environment (U), WSRC-RP-90-424-1, ca. $165 \mathrm{pp}$.

Siple, G.E., 1967, Geology and Ground Water of the Savannah River Plant and Vicinity, South Carolina, U.S. Geological Survey Water Supply Paper 1841, U.S. Government Printing Office, Washington, D.C., 113pp.

Solomon, D.K., and E.A. Sudicky, 1991, Tritium and helium 3 isotope rations for direct estimation of spatial variation in groundwater recharge, Water Resources Research, v. 27, p. 2309-2319. 
Appendix I. Monitoring well Construction and Tritium Analytical data.

\begin{tabular}{|c|c|c|c|c|c|c|}
\hline \multirow[t]{2}{*}{ WELL NO. } & \multirow{2}{*}{$\begin{array}{c}\text { MONITORED } \\
\text { UNIT(1) }\end{array}$} & FORMATION & \multirow{2}{*}{$\begin{array}{c}\text { AQUIFER } \\
\text { DESIGNATION }\end{array}$} & \multicolumn{2}{|c|}{ ELEVATIONS (FI } & \multirow{2}{*}{$\frac{M S L)}{E N \cdot}$} \\
\hline & & (FALLAW, '90) & & Casing & SCREE & \\
\hline$A \circlearrowleft B 8$ & $W T$ & Santer & $1 / 110$ & 349 & & 216.6 \\
\hline " (dupl.) & $n$ & $n$ & $1 / 11 C$ & " & & . \\
\hline$A S B 8 C$ & Upper Cong. & Congare日 & $1 / 11 \mathrm{C}$ & 349.7 & & 185.5 \\
\hline ASB 8 B & Lower Cong. & Fourmile & $1 / 110$ & 349.8 & & 125.6 \\
\hline ASB $8 \mathrm{~A}$ & Ellenton & Ellenton & $1 / 118 \cdot 1 / 11 C$ & 349.3 & & 80.7 \\
\hline ASB 8 TA & Black Cre日k & 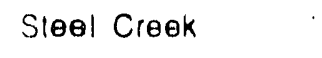 & $|i| \mid B$ & 349.6 & & 22 \\
\hline MSB 12 D & $W T$ & Dry Branch & $1 / 11 C$ & 346.3 & & 234.3 \\
\hline MSB $12 \mathrm{C}$ & Upper Cong. & Congaree & $1 / 11 \mathrm{C}$ & 347.9 & & 180.4 \\
\hline MSB $12 B$ & Upper Cong. & Fourmile & $1 / 11 \mathrm{C}$ & 348.4 & & 158.7 \\
\hline$M S B 12 \mathrm{~A}$ & Lower Corig. & Fourmile & $1 / 11 \mathrm{C}$ & 347.8 & & 118.4 \\
\hline MSB 12 TB & Black Creok & Ste日l Creek & $1 / 11 \mathrm{~B}$ & 348.5 & & 3.7 \\
\hline $\begin{array}{c}\text { MSB } 12 \text { TA } \\
\cdot \quad \text { (dupl.) }\end{array}$ & Black Creak & Black Creek & $1 / 118$ & $\begin{array}{r}348.5 \\
n\end{array}$ & & 108.7. \\
\hline MSB 33 & $W T$ & Dry Branch & $1 / 11 \mathrm{C}$ & 256.6 & & 219.3 \\
\hline MSB $33 \mathrm{C}$ & Upper Cong. & Conagree & $1 / 11 \mathrm{C}$ & 255.3 & & 170 \\
\hline MSB $33 \mathrm{~B}$ & Lower Cong. & Fourmile & $1 / 110$ & 255.2 & & 125.1 \\
\hline MS8 $33 \mathrm{~A}$ & Ellenton & Ellenton & $1 / 11 B \cdot 1 / 11 C$ & 255.4 & & 87.1 \\
\hline MSB 33 TA & Black Creek & Sle日l Cre日k & $1 / 11 \mathrm{~B}$ & 255.5 & & 22.3 \\
\hline MSB $34 \mathrm{C}$ & $w T$ & Santee \&Dry Br. & $1 / 11 \mathrm{C}$ & 383.2 & & 230.7 \\
\hline MSB $34 B$ & Upper Cong. & Congaree & $1 / 11 C$ & 383.1 & & 1843 \\
\hline MSB $34 \mathrm{~A}$ & Lower Cong. & Ellenton & $1 / 11 \mathrm{~B} \cdot 1 / 11 \mathrm{C}$ & 383.2 & & 115.8 \\
\hline MSB 34 TB & Black Creek & Steol Cie日k & $1 / 11 B$ & 382.8 & & 70.8 \\
\hline MSE 34 TA & Black Creek & Black Crook & $1 / 11 B$ & 382.5 & & .97 .7 \\
\hline MSB $36 \mathrm{D}$ & $w T$ & Dry Branch & $1 / 11 C$ & 341.5 & & 239.4 \\
\hline MSB $36 \mathrm{C}$ & Upper Cong. & Congaroe & $I / I 1 C$ & 340.8 & & 192 \\
\hline MSB $36 \mathrm{~B}$ & Lower Cong. & Fourmile & $1 / 11 C$ & 340.7 & & 162 \\
\hline MSB $36 \mathrm{~A}$ & Ellenton & 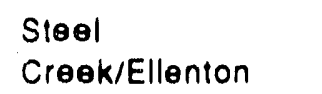 & $1 / 118 \cdot 1 / 11 C$ & 340.6 & & 99.1 \\
\hline MSB 36 TA & Black Croek & Siool Creok & $1 / 1 / B$ & 340.6 & & 52.5 \\
\hline MSB $37 D$ & NT & Dry Branch & $1 / 11 \mathrm{C}$ & 382.8 & & 236.1 \\
\hline MSB $37 \mathrm{C}$ & Upper Cong. & Congaree & $1 / 11 C$ & 383.1 & & 178.7 \\
\hline MSB $37 \mathrm{~B}$ & Lower Cong. & Fourmile & $1 / 11 C$ & 382.8 & & 140.9 \\
\hline MSB $37 \mathrm{~A}$ & Black Cre日k & Sle日l Creek & $1 / 11 B$ & 383.1 & & 71.7 \\
\hline MSB 37 TA & Black Creok & 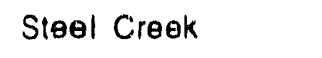 & $1 / 118$ & 382.4 & & 34.3 \\
\hline MSB $38 \mathrm{C}$ & Upper Cong. & Congare日 & $1 / 11 C$ & 356.3 & & 164.2 \\
\hline MSB 38 B & Lower Cong. & Fourmile & $1 / 11 C$ & 356.6 & & 141.7 \\
\hline MSB 38 TA & Black Creek & Steel Creek & $1 / 11 \mathrm{~B}$ & 356.7 & & 28.2 \\
\hline
\end{tabular}


Appendix I. Monitoring well Construction and Tritium Analytical data.

\begin{tabular}{|c|c|c|c|c|c|c|c|}
\hline \multirow[t]{2}{*}{ WELL NO. } & \multirow{2}{*}{$\begin{array}{l}\text { MONITORED } \\
\text { UNIT(1) }\end{array}$} & \multicolumn{2}{|c|}{ FOAMATION } & \multirow{2}{*}{$\begin{array}{l}\text { AQUIFER } \\
\text { DESIGNATION }\end{array}$} & \multirow{2}{*}{$\frac{\text { ELEVATIONS }}{\text { Caring }}$} & \multirow{2}{*}{$\frac{\text { (Ft }}{\text { SCRE }}$} & MSL) \\
\hline & & (FALLAW, & $90)$ & & & & EEN - \\
\hline MSB 390 & WT & Dry Branch & & $1 / 11 \mathrm{C}$ & 341.7 & & 230.2 \\
\hline MSB 39 C & Upper Cong. & Congaree & & $1 / 11 \mathrm{C}$ & 341.5 & & 197.8 \\
\hline MSB $39 \mathrm{~B}$ & Lower Cong. & Fourmile & & $1 / 11 C$ & 381.8 & & 149.9 \\
\hline MSB 39 A & Ellenton & Ellenton & & $1 / 11 \mathrm{~B} \cdot 1 / 11 \mathrm{C}$ & 341.6 & & 110 \\
\hline $\begin{array}{r}\text { MSB } 39 \text { TA } \\
" \text { (dupl.) }\end{array}$ & $\begin{array}{c}\text { Black Creøk } \\
\text {. }\end{array}$ & 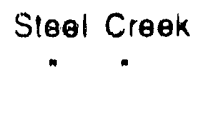 & & $1 / 118$ & 341.8 & & 48.3 \\
\hline MSB $40 \mathrm{D}$ & $W T$ & Dry Branch & & $1 / 110$ & 322.9 & & 226.7 \\
\hline MSB $40 \mathrm{C}$ & Upper Cong. & Santor & & $1 / 11 C$ & 322.1 & & 190 \\
\hline MSB 408 & Lower Cong. & Congareo & & $1 / 11 C$ & 321.7 & & 153 \\
\hline MSB $40 \mathrm{~A}$ & Ellenton & Ellenton & & $1 / 118 \cdot 1 / 11 C$ & 321.2 & & 114.9 \\
\hline $\begin{array}{c}\text { MSB } 40 \text { TA } \\
\cdot \text { (dUDI) }\end{array}$ & $\begin{array}{c}\text { Black Crenk } \\
\cdot\end{array}$ & 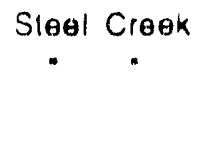 & & $1 / 118$ & 320.8 & " & 28.1 \\
\hline MSB $41 \mathrm{C}$ & Lower Cong. & Fourmile & & $1 / 11 C$ & 324.6 & & 150 \\
\hline$M S B \& 18$ & Ellenton & Ellenton & & $\mid / 1 / B \cdot 1 / 11 C$ & 324 & & 112.2 \\
\hline$M S B 41$ A & Ellenton & Ellenton & & $1 / 118 \cdot 1 / 11 C$ & 323.8 & & 86.3 \\
\hline MSB 41 TA & Black Creek & Steol Creok & & $|/| 1 B$ & 323.7 & & 25.5 \\
\hline MSB 470 & $W T$ & Santer & & $1 / 110$ & 369.2 & & 229.3 \\
\hline MSB $47 \mathrm{C}$ & Upper Cong. & Congares & & $1 / 110$ & 369.3 & & 199.8 \\
\hline$M S B A / B$ & Upper Cong. & Fourmile & & $1 / 11 \mathrm{C}$ & 369 & & 168.2 \\
\hline MSB $47 \mathrm{TA}$ & Black Creok & Steol Creak & & $1 / 118$ & 369 & & 52.8 \\
\hline MSB 540 & Waler Table & Dry Branch & & $1 / 11 C$ & 374 & & 234 \\
\hline MSB $54 \mathrm{C}$ & Uppor Cong. & Fourmile & & $1 / 11 \mathrm{C}$ & 373.7 & & 173.1 \\
\hline MSB 54 B & Lower Cong. & Fourrnile & & $1 / 11 C$ & 373.7 & & 134 \\
\hline $\begin{array}{r}\text { MSB } 54 \text { TA } \\
\text { * (dupl) }\end{array}$ & $\begin{array}{c}\text { Black Crook } \\
.\end{array}$ & Sioel Crook & & $1 / 118$ & 373.8 & & $\begin{array}{r}78.4 \\
.\end{array}$ \\
\hline MSB $69 \mathrm{D}$ & $W T$ & Santer/Dry & Branch & $1 / 11 C$ & 382.2 & & 230.2 \\
\hline MSB $69 \mathrm{C}$ & Upper Cong. & Fourmilo & & $1 / 11 C$ & 381.8 & & 173.4 \\
\hline$M S B 69 B$ & Lower Cong. & Fourmile & & $1 / 11 C$ & 381.7 & & 142.4 \\
\hline MSB $69 \mathrm{TA}$ & Black Croek & Steol Creok & & $1 / 118$ & 381.5 & & 77.6 \\
\hline
\end{tabular}

(1) unil designated in monitor well data reports and databases.

- MIDPOINT OF SCREENED INTERVAL. 
Appendix I. Monitoring well Construction and Tritium Analytical data.

\begin{tabular}{|c|c|c|c|c|c|}
\hline WELL NO. & $\begin{array}{l}\text { SAMPLE } \\
\text { DATE }\end{array}$ & \multicolumn{2}{|c|}{ REPLICATEANALYSES } & $\begin{array}{l}\text { Moan } \\
\mathrm{pCl/g}\end{array}$ & $\begin{array}{c}\text { Moan } \\
\text { TU }\end{array}$ \\
\hline ASB 8 & $5 / 44 / 89$ & 2.839 & 2.938 & 2.889 & 902.7 \\
\hline " (dupl.) & $5 / 14 / 89$ & 2.986 & 2.736 & 2.861 & 894.1 \\
\hline ASB $8 \mathrm{C}$ & $5 / 14 / 89$ & 23.353 & 24.020 & 23.687 & 7402.0 \\
\hline ASB 8 B & $5 / 14 / 89$ & 1.367 & 1.482 & 1.425 & 445.2 \\
\hline ASB 8 A & $5 / 14 / 89$ & 0.174 & 0.154 & 0.164 & 51.3 \\
\hline ASB 8 TA & $5 / 14 / 89$ & 0.029 & 0.031 & 0.03 & 3.4 \\
\hline MSB 120 & - dry hole & & & & \\
\hline MSB $12 \mathrm{C}$ & $4 / 27 / 89$ & 0.245 & 0.277 & 0.261 & 81.6 \\
\hline MSB $12 \mathrm{~B}$ & $4 / 27 / 89$ & 0.349 & 0.388 & 0.369 & 115.2 \\
\hline MSB $12 \mathrm{~A}$ & $4 / 27 / 89$ & 0.020 & 0.047 & 0.034 & 10.5 \\
\hline MSB 12 TB & $4 / 27 / 89$ & $<.013$ & $<.012$ & $<.012$ & 0.0 \\
\hline MSB 12 TA & $4 / 27 / 89$ & 0.002 & $<.018$ & 0.002 & 0.6 \\
\hline * (dupl.) & $4 / 27 / 89$ & 0.051 & 0.034 & 0.043 & 13.3 \\
\hline MSB 33 & $4 / 25 / 89$ & 0.869 & 0.881 & 0.875 & 273.4 \\
\hline MSB $33 \mathrm{C}$ & $4 / 25 / 89$ & 2.288 & 8.816 & 5.552 & 1735.0 \\
\hline MSB 33 B & $4 / 25 / 89$ & 0.863 & 0.862 & 0.863 & 269.5 \\
\hline MSB 33 A & $4 / 25 / 89$ & 0.051 & 0.013 & 0.032 & 10.0 \\
\hline MSB 33 TA & $4 / 25 / 89$ & 0.011 & 0.053 & 0.032 & 10.0 \\
\hline$M S B 34 \mathrm{C}$ & $5 / 8 / 89$ & 0.773 & 0.821 & 0.797 & 249.1 \\
\hline MSB $34 \mathrm{~B}$ & $5 / 8 / 89$ & 0.991 & 0.972 & 0.982 & 306.7 \\
\hline MSB $34 \mathrm{~A}$ & $5 / 8 / 89$ & 0.284 & 0.271 & 0.278 & 86.7 \\
\hline MSB 34 TB & $5 / 8 / 89$ & 0.010 & 0.005 & 0.008 & 2.3 \\
\hline MSB 34 TA & $5 / 8 / 89$ & 0.036 & 0.011 & 0.024 & 7.3 \\
\hline MSB 36 D & $5 / 17 / 89$ & 0.042 & 0.276 & 0.159 & 49.7 \\
\hline MSB $36 \mathrm{C}$ & $6 / 3 / 89$ & 0.864 & 0.903 & 0.884 & 276.1 \\
\hline MSB 368 & $6 / 3 / 89$ & 0.361 & 0.391 & 0.376 & 117.5 \\
\hline MSB $36 \mathrm{~A}$ & $6 / 3 / 89$ & 0.014 & 0.038 & 0.026 & 8.1 \\
\hline MSB 36 TA & $6 / 3 / 89$ & 0.022 & $<.019$ & 0.022 & 6.9 \\
\hline MSB 37 D & $5 ! 11 / 89$ & 1452 & 1.272 & 1362 & 4256 \\
\hline MSB $37 \mathrm{C}$ & $5 / 11 / 89$ & 0.751 & 0.739 & 0.745 & 232.8 \\
\hline MS8 37 B & $5 / 11 / 89$ & 0.355 & 0.331 & 0.343 & 107.2 \\
\hline MSB 37 A & $5 / 11 / 89$ & 0.333 & 0.280 & 0.307 & 95.8 \\
\hline MSB 37 TA & $5 / 11 / 89$ & 0.805 & 0.769 & 0.787 & 245.9 \\
\hline MSB $38 \mathrm{C}$ & $5 / 16 / 89$ & 0.859 & 1.164 & 1.012 & 310.1 \\
\hline$M S B 3 B B$ & $5 / 16 / 89$ & 0.475 & 0.612 & 0.544 & 169.8 \\
\hline MSB 38 TA & $5 / 16 / 89$ & 0.035 & & 0.035 & 10.9 \\
\hline
\end{tabular}


Appendix I. Monitoring well Construction and Tritium Analytical data.

\begin{tabular}{|c|c|c|c|c|c|}
\hline WELL NO. & $\begin{array}{l}\text { SAMPLE } \\
\text { DATE }\end{array}$ & \multicolumn{2}{|c|}{ REPLICATEANALYSES } & $\begin{array}{l}\text { Moan } \\
\mathrm{pCl} / \mathrm{g}\end{array}$ & $\begin{array}{c}\text { Moan } \\
\text { TU }\end{array}$ \\
\hline MSB 39 D & $5 / 3 / 89$ & 2.207 & 0.864 & 1.536 & 479.8 \\
\hline MSB $39 \mathrm{C}$ & $5 / 3 / 89$ & 1.464 & 1.339 & 1.402 & 438.0 \\
\hline MSB 39 B & $5 / 3 / 89$ & 0.256 & 0.227 & 0.242 & 75.5 \\
\hline MSB 39 A & $5 / 3 / 89$ & 0.026 & 0.012 & 0.019 & 5.9 \\
\hline MSB 39 TA & $5 / 3 / 89$ & $<.023$ & $<.017$ & $<.020$ & 0.0 \\
\hline • (dupl.) & $5 / 3 / 89$ & 0.002 & 0.035 & 0.019 & 5.8 \\
\hline MSB $40 \mathrm{D}$ & $5 / 11 / 89$ & 2.334 & 2.172 & 2.253 & 704.1 \\
\hline MSB $40 \mathrm{C}$ & $5 / 10 / 89$ & 0.007 & 0.004 & 0.006 & 1.7 \\
\hline MSB $40 \mathrm{~B}$ & $5 / 10 / 89$ & 0.043 & 0.031 & 0.037 & 11.6 \\
\hline$M S B 40 \mathrm{~A}$ & $5 / 10 / 89$ & $<0.134$ & 0.036 & 0.036 & 11.3 \\
\hline MSB $40 \mathrm{TA}$ & $5 / 10 / 89$ & 0.009 & 0.076 & 0.043 & 13.3 \\
\hline "(dupl) & $5 / 10 / 89$ & 0.009 & 0.043 & 0.026 & 8.1 \\
\hline $\mathrm{MSB} 41 \mathrm{C}$ & $5 / 4 / 89$ & 1.050 & 1.037 & 1.044 & 326.1 \\
\hline MSB $41 B$ & $5 / 4 / 89$ & 0.413 & 0.344 & 0.379 & 118.3 \\
\hline MSB $41 \mathrm{~A}$ & $5 / 4 / 89$ & 0.085 & 0.026 & 0.056 & 17.3 \\
\hline MSB 41 TA & $5 / 4 / 89$ & 0.048 & 0.025 & 0.037 & $\begin{array}{r}11.4 \\
0.0\end{array}$ \\
\hline MSB $47 \mathrm{D}$ & $4 / 28 / 89$ & 1.786 & 1.890 & 1.838 & 574.4 \\
\hline MSB $47 \mathrm{C}$ & $4 / 28 / 89$ & 24.041 & 22.056 & 23.049 & 7202.7 \\
\hline MSB 47 B & $4 / 28 / 89$ & 5.174 & 5.169 & 5.172 & 1616.1 \\
\hline MSB $47 \mathrm{TA}$ & $4 / 28 / 89$ & 0.640 & 0.724 & 0.682 & 213.1 \\
\hline MSB 54 D & $5 / 7 / 89$ & 1.722 & 1.663 & 1.693 & 528.9 \\
\hline MSB $54 \mathrm{C}$ & $5 / 7 / 89$ & 0.033 & 0.565 & 0.299 & 93.4 \\
\hline MSB 54 B & $5 / 7 / 89$ & 0.063 & 0.024 & 0.044 & 13.6 \\
\hline MSB 54 TA & $5 / 7 / 89$ & 0.050 & 0.074 & 0.062 & 19.4 \\
\hline$\cdot(d u p l)$ & $5 / 7 / 89$ & 0.053 & 0.069 & 0.061 & 19.1 \\
\hline MSB $69 \mathrm{D}$ & $4 / 28 / 89$ & 1.088 & 1.677 & 1.383 & 432.0 \\
\hline MSB $69 \mathrm{C}$ & $4 / 28 / 89$ & 0.907 & 1.122 & 1.015 & 317.0 \\
\hline MSB 69 B & $4 / 28 / 89$ & $<.010$ & • & $<.010$ & 0.0 \\
\hline MSB $69 T A$ & $4 / 27 / 89$ & 0.034 & 0.035 & 0.035 & 10.8 \\
\hline
\end{tabular}


$\approx$
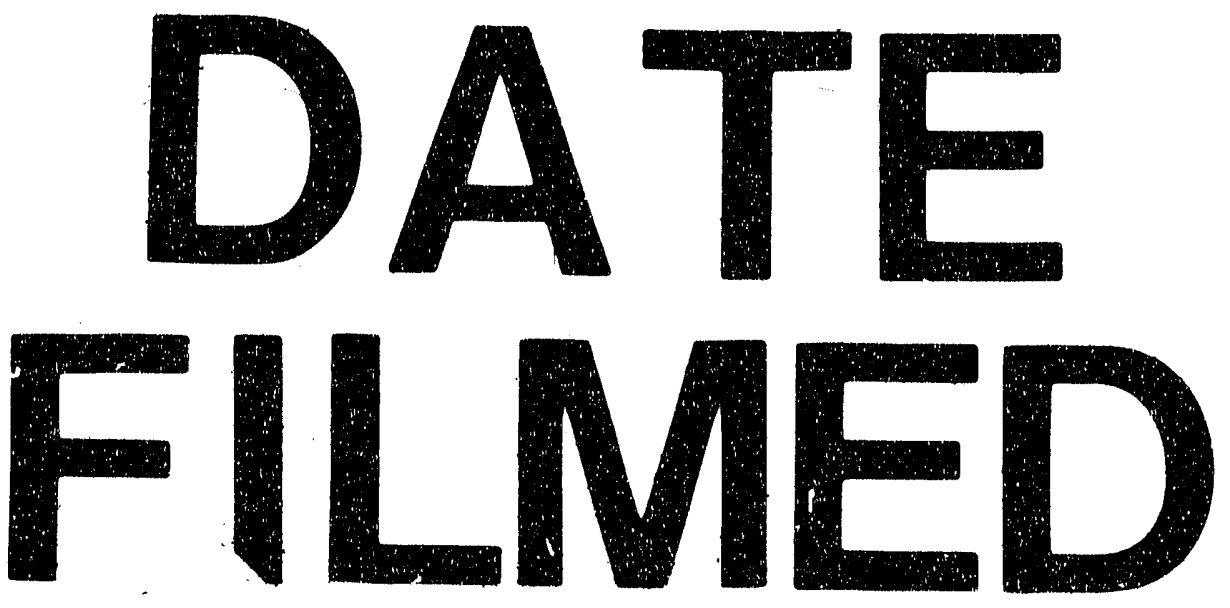

8120192 
